\title{
御影石を模擬したコンクリート二次製品の 異常膨張現象
}

\author{
松下 博通*1 ・ 川端雄一郎*2
}

\begin{abstract}
概 要 近年, 特殊な配合で製造されるコンクリート縁石ブロックの異常膨張現象が福岡県, 山口県, 岡山県において 発見されており，これらの早期対応が求められている。本稿はコンクリート二次製品の異常膨張の原因についてこれらの 劣化事例とその原因について報告するものである。異常膨張を生じたコンクリート二次製品は白色セメント, 石灰石骨材, 銅スラグという使用材料により御影石を模擬した縁石ブロックである。各種実験および分析結果から, 異常膨張を生じた コンクリート二次製品には $80^{\circ} \mathrm{C}$ を超えるような過剩な蒸気養生を行った可能性が高いこと, 石灰石骨材界面においてエ トリンガイトが生成していることが明らかになった。以上から, 本研究の対象としたコンクリート二次製品の異常膨張は Delayed Ettringite Formation（DEF）であると推察された。

キーワード：異常膨張, 白色ポルトランドセメント, 石灰石, 銅スラグ, 蒸気養生, エトリンガイト, DEF
\end{abstract}

\section{1.はじめに}

近年におけるコンクリート構造物の早期劣化は社会問 題として取り上げられ，コンクリートはメンテナンスフ リーであるという概念は覆され，コンクリート構造物の 維持管理のあり方に関して様々な議論が行われている。 コンクリートの耐久性のうち，一般的に認知されている むのとして中性化，塩害，アルカリ骨材反応，凍害，化 学的侵食が挙げられる。これらのうち, 中性化, 塩害に ついては性能照査のための予測式等が提案されており, 今後のコンクリート構造物の維持管理のためのシステム が着々と構築されつつある。

一方, 今後コンクリート構造物の性能照查を行う上で 化学的侵食についての知見は十分ではない1。化学的侵 食は，酸や硫酸塩といった種々の要因によって複合的に 作用する, 非常に複雑かつ局地的な劣化現象であり, 統 一的見解が困難である。そのため, 2002 年制定のコン クリート標準示方書 [施工編]に扔いては, 耐化学的侵食 性を確保するための最大 $W / C$ が定められているのみで あり，劣化予測手法に関する具体的記述は無い。これら の現状は化学的侵食に対する予測手法に対して検討の余 地が十分ではないことを示している。

また，近年において福岡県，山口県扔よび岡山県を中 心としてコンクリート二次製品が膨張するという事例が 多数報告されている。異常膨張を生じたコンクリート二 次製品は，コンクリート二次製品工場によってそれぞれ 配合が異なるものの，いずれむ御影石を模擬した製品で ある。しかし, 現段階においては異常膨張の劣化原因が

*1 まつした・ひろみち/九州大学大学院 工学研究院 建設デザイ ン部門 教授 (正会員)

＊2 かわばた・ゆういちろう/九州大学大学院 工学府 建設システ 厶工学専攻 (正会員)
特定されておらず，十分な対応がされていないため，早 期対策を講じる必要がある。

本稿は, 異常膨張を生じたコンクリート二次製品の劣 化被害状況や共通点を明確にし，各種分析に基づき劣化 原因について検討を行ったものである。

\section{2. コンクリート二次製品の劣化被害状況}

\section{1 劣化被害状況}

本研究が対象としたコンクリート二次製品の膨張事例 は 12 件である。表-1は本研究が対象としたコンクリート 二次製品の異常膨張劣化事例とその特徴を記載している。

製品工場 A で製造されたコンクリートは全て同一の 使用材料および配合のものであるが，劣化までの期間は 平均的には $2 \sim 3$ 年である。曝露環境の詳細は後述する が，歩道や道路の境界もしくは歩道と植樹帯の境界に使 用しており，近辺の他のコンクリート二次製品には劣化 が見られなかった。

\section{表-1 コンクリート二次製品の異常膨張被害状況}

\begin{tabular}{|c|c|c|c|c|}
\hline 事例 & $\begin{array}{l}\text { 製品 } \\
\text { 工場 }\end{array}$ & $\begin{array}{l}\text { 製品の } \\
\text { 種類 }\end{array}$ & 設置場所 & $\begin{array}{l}\text { 劣化発生 } \\
\text { までの期間 }\end{array}$ \\
\hline 1 & \multirow{9}{*}{ A } & 縁石 & 道路・歩道 & $2 \sim 3$ 年 \\
\hline 2 & & 縁石 & 道路・歩道 & $7 \sim 8$ 年 \\
\hline 3 & & 縁石 & 道路・歩道 & $2 \sim 3$ 年 \\
\hline 4 & & 縁石 & 道路・歩道 & $1 \sim 2$ 年 \\
\hline 5 & & 縁石 & 歩道 & $2 \sim 3$ 年 \\
\hline 6 & & 平板 & 公園階段 & $4 \sim 5$ 年 \\
\hline 7 & & 平板 & 広場 & 1年 \\
\hline 8 & & 縁石 & 広場 & 1年 \\
\hline 9 & & 縁石 & 歩道 & 半年 \\
\hline 10 & \multirow{2}{*}{ B } & 縁石 & 道路・歩道 & $2 \sim 3$ 年 \\
\hline 11 & & 縁石 & 道路・歩道 & $2 \sim 3$ 年 \\
\hline 12 & C & 縁石 & 道路・歩道 & $2 \sim 3$ 年 \\
\hline
\end{tabular}




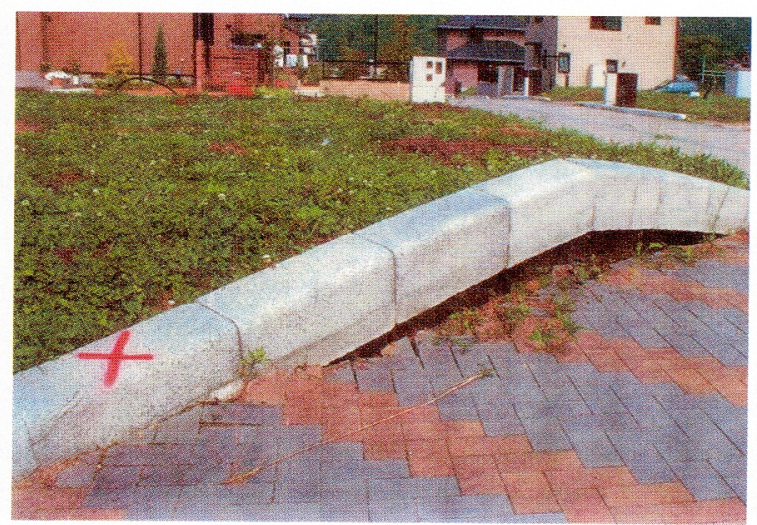

写真-1 劣化事例 1

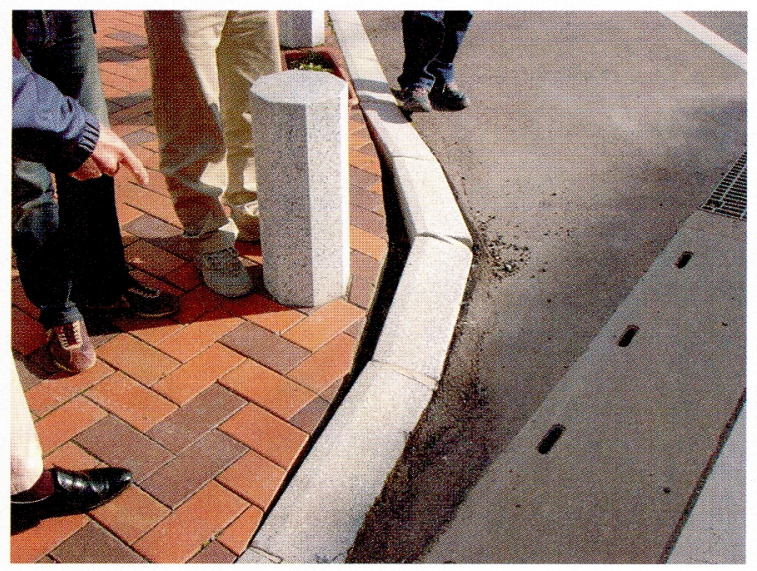

写真-2 劣化事例 3

製品工場 B で製造されたコンクリート屯製品工場 A とほぼ同様の使用材料および配合である。製品工場 C で製造されたコンクリートは，細骨材に花崗岩を使用し ている点は異なるものの, その他の使用材料抢よび配合 は同様のものである。

写真-1 はコンクリート二次製品の膨張劣化事例 1 で ある。コンクリート製品である縁石ブロックが膨張し, アーチ状にせり出している状況である。アーチ状の頂点 部付近の縁石ブロックでは曲げひび割れが発生していた。 これら全ての縁石ブロックが一様に膨張していると仮定 して縁石ブロックの膨張率を求めたところ, 約 $0.4 \%$ で あった。
写真-2 は膨張劣化事例 3 を示している。上述したコ ンクリートと同じ配合であるが，異なる製品の膨張劣化 である。写真に示す劣化事例 3 は歩行者道路に設置した 縁石ブロックが膨張し，写真右下方向にせり出したこと によりアスファルト舗装が盛り上がっている状況が確認 できる。劣化を生じた縁石ブロックの表面には無数のク ラックが発生していた。

\section{2 コンクリートの曝露環境}

異常嘭張を生じたコンクリート二次製品は，いずれも 水分を多く供給される屋外に曝露されており, 劣化因子 の侵入や反応を促進させる乾湿の影響が大きい。ただし， 同じ曝露環境下に扔いても劣化を生じていないコンクリー 卜二次製品も確認されている。

コンクリートが膨張劣化を生じる要因として, 使用材 料自身の問題之外部からの劣化因子の侵入の問題の 2 点 に大別できる。そこで，本研究は膨張したコンクリート が曝露された箇所の地質調査を行った。しかし, 硫化鉱 物を含有する地盤2ではなかった。

さらに，劣化が確認された縁石ブロックの周辺にある インターロッキングブロックに使用されたコンクリート には全く劣化が認められないこと, 劣化を生じた縁石ブ ロック表面に析出物等が見られないことから外部硫酸塩 の侵入による劣化は無いものと考えられた。

また，寒冷環境においては凍害による劣化の可能性も 考えられるが，九州地方を中心に報告されている劣化現 象であること, 気象データから, 凍結融解による影響は 無いものと考えられた。

2. 3 コンクリートの使用材料, 配合および製造方法

異常膨張を生じたコンクリート二次製品の使用材料押 よび配合を，製品工場 $\mathrm{A}$ を一例として表-2，表-3 に示 す。コンクリート二次製品工場によって $W / C$ や $s / a$ が 多少異なり，一部の製品工場においては細骨材に花崗岩 を使用しているものもあるが，天然の御影石を模擬した 製品となっている。これらのコンクリート二次製品は目 標スランプ $8 \mathrm{~cm}$, 目標空気量 $2 \%$ であり, 全て蒸気養 生を行って製造されている。

Expansion of Curbstone Concrete Imitated Granite By H. Matsushita and Y. Kawabata

\author{
Concrete Journal, Vol.43, No.12, pp.32 38, Dec. 2005
}

Synopsis Recently, the failure of curbstone concrete have been reported in Fukuoka, Yamaguchi and Okayama Prefecture. The concrete have been characterized by expansion and cracking after several years of service in environments exposed in water. The concrete consists of white cement, limestone and copper slag and it has been manufactured at elevated temperatures for early shipment. As a result, examination identified delayed ettringite formation (DEF) as the damaging mechanism. SEM-EDX analysis identified that ettringite accumulated around limestone in damaged concrete. Therefore, this study concluded that expansion of curbstone concrete have been due to delayed ettringite formation because of steam curing above $80 \mathrm{deg} \mathrm{C}$ and the reaction between calcite and monosulfate.

Keywords : expansion, white portland cement, limestone, copper slag, steam curing, ettringite, DEF 


\section{表-2 使用材料の一例}

\begin{tabular}{|c|c|}
\hline & 使用材料 \\
\hline セメント & $\begin{array}{l}\text { 白色ポルトランドセメント } \\
\text { 密度 } 3.06 \mathrm{~g} / \mathrm{cm}^{3} \text {, 比表面積 } 3580 \mathrm{~cm}^{2} / \mathrm{g}\end{array}$ \\
\hline \multirow{2}{*}{ 細骨材 } & $\begin{array}{l}\text { 石灰石 } \\
\text { 絶乾密度 } 2.70 \mathrm{~g} / \mathrm{cm}^{3} \text {, 吸水率 } 0.54 \%\end{array}$ \\
\hline & $\begin{array}{l}\text { 銅スラグ } \\
\text { 絶乾密度 } 3.46 \mathrm{~g} / \mathrm{cm}^{3}, \text { 吸水率 } 0.42 \%\end{array}$ \\
\hline 粗骨材 & $\begin{array}{l}\text { 石灰石 } \\
\text { 絶乾密度 } 2.70 \mathrm{~g} / \mathrm{cm}^{3} \text {, 吸水率 } 0.54 \%\end{array}$ \\
\hline
\end{tabular}

表-3 示方配合の一例

\begin{tabular}{|c|c|c|c|c|c|}
\hline \multirow{3}{*}{$\begin{array}{l}W / C \\
(\%)\end{array}$} & \multicolumn{5}{|c|}{ 単位量 $\left(\mathrm{kg} / \mathrm{m}^{3}\right)$} \\
\hline & \multirow{2}{*}{$\begin{array}{l}\text { 水 } \\
W\end{array}$} & \multirow{2}{*}{$\begin{array}{c}\text { セメント } \\
C\end{array}$} & \multicolumn{2}{|c|}{$\begin{array}{c}\text { 細骨材 } \\
S\end{array}$} & \multirow{2}{*}{$\begin{array}{c}\text { 粗骨材 } \\
G\end{array}$} \\
\hline & & & 石灰石 & 銅スラグ & \\
\hline 49 & 180 & 367 & 1201 & 272 & 422 \\
\hline
\end{tabular}

\section{4 コンクリートニ次製品の異常膨張現象の共通点}

以上から，異常膨張を生じたコンクリート二次製品に は以下の上うな共通点があることが分かった。

1） 天然の御影石に模擬するために，粗骨材として石 灰石を使用し，細骨材には石灰石または花崗岩を使 用している。銅スラグを細骨材体積の $15 \%$ 程度混 入し，白色ポルトランドセメントを使用している。

2）蒸気養生を行ったコンクリート二次製品のみ洁張 している。

3）水分が供給される屋外に曝露されたコンクリート 二次製品のみ膨張している。

本研究は上述した 3 点の共通点に着目して各種分析お よび実験的検討を行った。以降では，代表として劣化事 例 1 で異常膨張が認められたコンクリート二次製品につ いて各種分析を行ったものを示している。

\section{3. 膨張劣化因子の特定}

\section{1 使用材料の化学成分および鉱物組成}

表-4 に異常膨張を生じたコンクリート二次製品で使 用した白色ポルトランドセメント（WPC）の化学成分 を示す。あわせて, 普通术ルトランドセメント (OPC) の化学成分についても記載している。WPC は OPC と 比較して $\mathrm{Al}_{2} \mathrm{O}_{3}, \mathrm{Fe}_{2} \mathrm{O}_{3}$ が少ない。しかし, Bogue 式か ら求まる $\mathrm{WPC}$ の $\mathrm{C}_{3} \mathrm{~A}$ 量は $12 \%$ であり, $\mathrm{OPC}$ の $9 \%$ よりも多い。また, $\mathrm{WPC}$ の $\mathrm{SO}_{3}$ 量は $\mathrm{C}_{3} \mathrm{~A}$ 量に合わせて

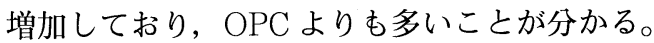

石灰石をコンクリート用骨材として使用した際，アル カリ炭酸塩反応 (ACR) が危惧される3)。また，銅スラ グの一般的な化学組成は，全鉄が 41〜 54\%，シリカが 29〜37\% の值を示し，この両者で大半を占めている。 よって，銅スラグは鉄分に由来する錆の影響や ASR 反 応性が䯚念される。

表-5，表-6に石灰石と銅スラグの化学成分をそれぞ れ示す。石灰石は $\mathrm{CaO}$ がほとんどを占めており，アル カリ炭酸塩反応（ACR）の原因となるドロマイトが含 有する $\mathrm{MgO}$ はほとんど含まれていない。また, CSA A 23. 2-26A の ACR 反応性を判定するグラフにプロット したところ，「non-expansive」と判定された。また， 珪質石灰石に扔いてはシリカ鉱物の ASR 反応む考元ら れる。しかし， $\mathrm{SiO}_{2}$ 量が少ないことから，その可能性 も低い。

銅スラグについてはシリカと鉄分が主成分であった。 本研究による銅スラグの化学分析值は一般的な組成) と ほぼ同等の值を示しており，特殊な銅スラグではないこ とが分かる。また，銅スラグを対象に ASR 判定用化学 法を適用したところ，それぞれ溶解シリカ量 $\mathrm{Sc}=42$ $\mathrm{mmol} / \mathrm{l}$, アルカリ濃度減少量 $\mathrm{Rc}=43 \mathrm{mmol} / \mathrm{l}$ であり,

表-4 セメントの化学組成

\begin{tabular}{c|c|c|c|c|c|c|c|c|c|c|c|c|c}
\hline & \multicolumn{10}{c}{ 組成割合 (\%) } \\
\cline { 2 - 37 } & Ig. loss & $\mathrm{SiO}_{2}$ & $\mathrm{Al}_{2} \mathrm{O}_{3}$ & $\mathrm{Fe}_{2} \mathrm{O}_{3}$ & $\mathrm{CaO}$ & $\mathrm{MgO}$ & $\mathrm{SO}_{3}$ & $\mathrm{Na}_{2} \mathrm{O}$ & $\mathrm{K}_{2} \mathrm{O}$ & $\mathrm{TiO}_{2}$ & $\mathrm{P}_{2} \mathrm{O}_{5}$ & $\mathrm{MnO}$ & $\mathrm{Cl}$ \\
\hline WPC & 2.98 & 23.34 & 4.80 & 0.16 & 66.02 & 0.81 & 2.66 & 0 & 0.09 & 0.16 & 0.01 & 0.12 & 0.01 \\
\hline OPC & 0.66 & 21.49 & 5.41 & 2.88 & 64.76 & 1.02 & 1.78 & 0.10 & 0.37 & 0.28 & 0.22 & 0.12 \\
\hline
\end{tabular}

表-5 石灰石の化学組成

\begin{tabular}{c|c|c|c|c|c|c|c|c|c|c|c|c|c}
\hline & \multicolumn{10}{c}{ 組成割合 (\%) } \\
\cline { 2 - 33 } & Ig.loss & $\mathrm{SiO}_{2}$ & $\mathrm{Al}_{2} \mathrm{O}_{3}$ & $\mathrm{FeO}$ & $\mathrm{CaO}$ & $\mathrm{MgO}$ & $\mathrm{SO}_{3}$ & $\mathrm{Na}_{2} \mathrm{O}$ & $\mathrm{K}_{2} \mathrm{O}$ & $\mathrm{TiO}_{4}$ & $\mathrm{MnO}_{2}$ & $\mathrm{P}_{2} \mathrm{O}_{5}$ & Total \\
\hline 粗骨材 & 43.94 & 0.09 & 0.02 & 0.02 & 55.42 & 0.43 & 0 & 0.01 & 0 & 0.02 & 0.01 & 0.01 & 99.97 \\
\hline 細骨材 & 43.92 & 0.09 & 0.08 & 0.02 & 55.18 & 0.49 & 0 & 0.01 & 0 & 0.02 & 0.01 & 0.02 & 99.84 \\
\hline
\end{tabular}

表-6 銅スラグの化学組成

\begin{tabular}{c|c|c|c|c|c|c|c|c|c|c|c|c}
\hline & \multicolumn{10}{c}{ 組成割合 (\%) } \\
\cline { 2 - 24 } & $\mathrm{T}-\mathrm{Fe}$ & $\mathrm{SiO}_{2}$ & $\mathrm{Al}_{2} \mathrm{O}_{3}$ & $\mathrm{CaO}$ & $\mathrm{MgO}$ & $\mathrm{ZnO}$ & $\mathrm{CuO}$ & $\mathrm{SO}_{3}$ & $\mathrm{Na}_{2} \mathrm{O}$ & $\mathrm{Cl}$ & Total \\
\hline 銅スラグ & 39.20 & 43.63 & 4.82 & 2.44 & 1.72 & 1.22 & 0.98 & 0.39 & 0.63 & 1.43 & 0.06 & 96.52 \\
\hline
\end{tabular}




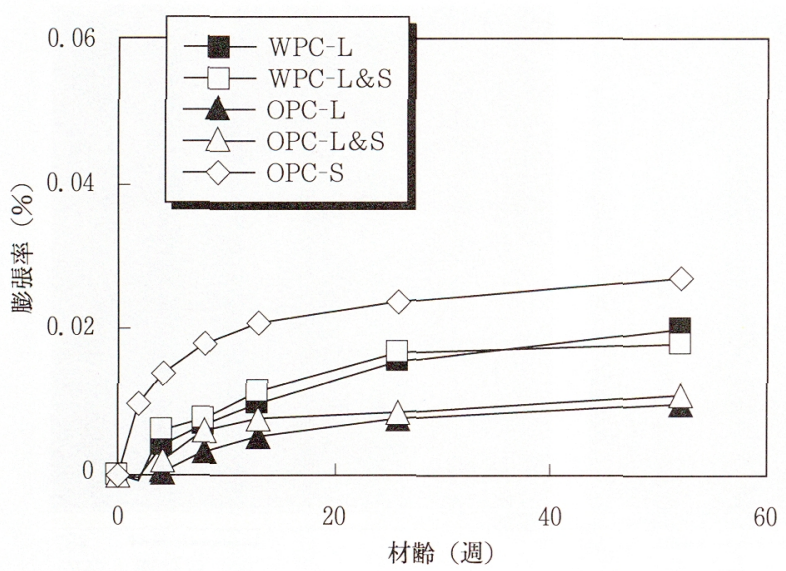

図-1＼cjkstart使用骨材の AAR 反応性（JIS A 1146）

「無害」と判定された。なお，一般的な銅スラグの Sc, Rc はとむに $40 \mathrm{mmol} / \mathrm{l}$ 程度以下である。

石灰石の鉱物組成については，カルサイトが主成分で あり，ドロマイトはほとんど存在していない。また，銅 スラグについては非晶質とともに微量のファイアライト が同定された。石灰石および銅スラグともに一般的な鉱 物組成であることから，化学成分および鉱物組成の観点 からは使用骨材のみによって膨張劣化につながったもの とは考え難い。

\section{2 骨材とセメントの組合せによる AAR 反応性}

骨材のAAR 反応性を調べるため，JIS A 1146 に準 拠して石灰石扔よび銅スラグを使用してモルタルバー法 を 1 年間にわたって行った。また，骨材やセメントの組 合せによる影響5も考えられる。そこで，各種組合せに よってモルタルバーの膨張率を 1 年間測定した。

モルタルバー法による試験結果を図-1 に示す。Lは 石灰石のみ，L\&S は石灰石に一部銅スラグを混入した むの， S は銅スラグのみを細骨材に使用したことを示し ている。石灰石および銅スラグのみを使用したモル夕ル の膨張率は $0.03 \%$ 以下であり，ほとんど膨張していな いことが分かる。銅スラグが最も膨張を生じているが， ガラス相の微弱な ASR 反応性であると考えられる。し かし，いずれも $0.03 \%$ 以下であり，「無害」と判定された。

以上から，コンクリート二次製品の異常膨張は骨材種 類やセメントとの組合せによる AAR 膨張も生じないこ とが分かった。

\section{3 銅スラグの反応性}

銅スラグについては上述したように，鉄分を多く含む ために錆の影響が懸念される。よって，本研究では EPMA を用いてコンクリート二次製品中の銅スラグに ついて BSE 像を観察した。銅スラグが何らかの反応を 生じた場合，平均原子番号を基にした銅スラグ界面の BSE 像は反応環のように暗く見える。しかし，写真-3 に示すように反応環は見られず，コンクリート二次製品 中の銅スラグはほとんど反応を生じていないことが確認 された。以上から，銅スラグについては異常膨張に大き

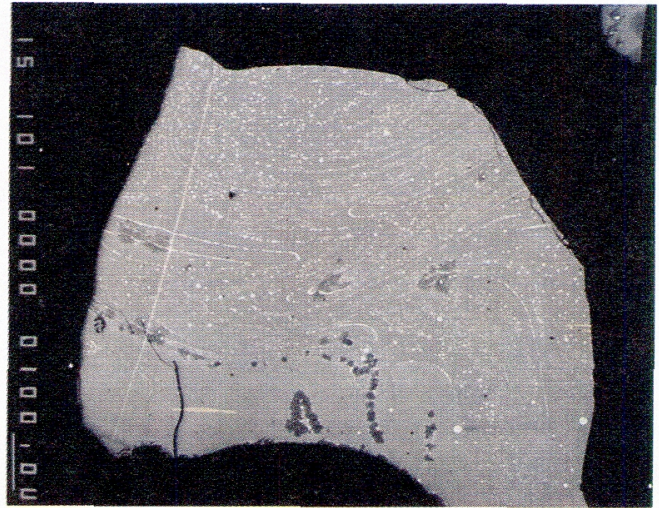

写真-3＼cjkstart銅スラグの BSE 像

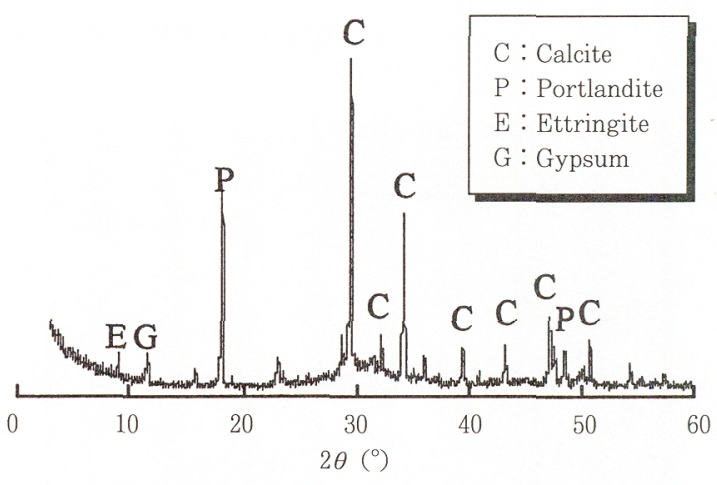

図-2 コンクリートニ次製品中の生成物

く奇与していないと考えられた。

\section{4 膨張性生成物の同定}

本研究は, 異常膨張を生じたコンクリート二次製品に ついて XRD 分析を行い，膨張性生成物の同定を行った。 図-2 は異常膨張を生じたコンクリート二次製品から採 取したモルタル片の XRD 分析結果である。縁石ブロッ クは骨材に石灰石を使用しており，酸処理を行えなかっ たため, カルサイトのピークが大きく検出されている。 また，水酸化カルシウムの他にエトリンガイトと二水せっ こうが検出された。この傾向は他の膨張を生じたコンク リート二次製品についても確認された。エトリンガイト のX線強度は小さいが，外部硫酸塩劣化に打けるエト リンガイトの生成量が小さい場合でも劣化を生じている ものも報告されている。

\section{5 コンクリート二次製品の異常膨張現象の原因推定}

以上から，コンクリート二次製品の異常膨張現象は石 灰石や銅スラグの AAR ではないことが確認された。ま た，銅スラグは反応を生じていなかった。ソーマサイト 硫酸塩劣化》 は低温地における劣化であること，後述す るように SEM-EDX により膨張生成物はエトリンガイ トと判別されたことからソーマサイトの生成による劣化 は無いものといえる。また，XRDによりエトリンガイ トが同定されたことから，DEF ${ }^{8)}$ である可能性は否定で きない。

よって，コンクリート二次製品の異常膨張現象として 最も可能性の大きい DEF に重点をおいて詳細に検討す 


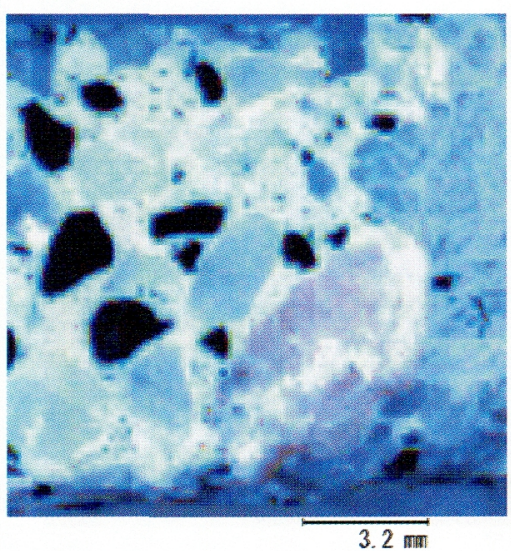

(a) 光学像

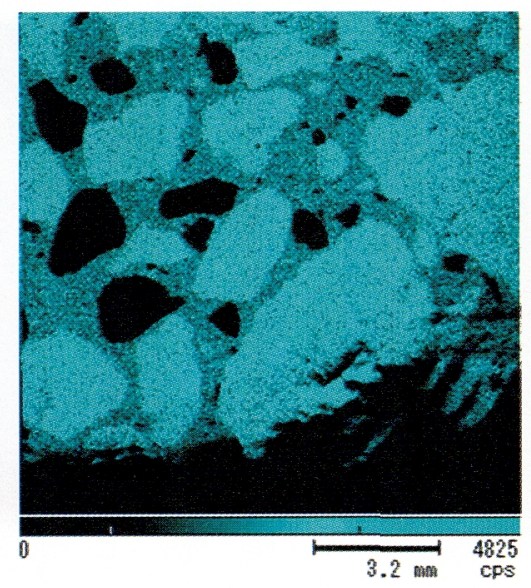

(b) $\mathrm{Ca}$

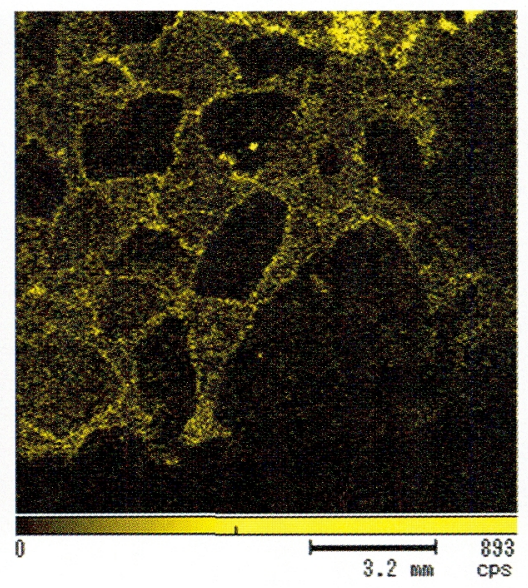

(c) $\mathrm{S}$

写真-4 異常膨張を生じたコンクリート二次製品の元素マッピング

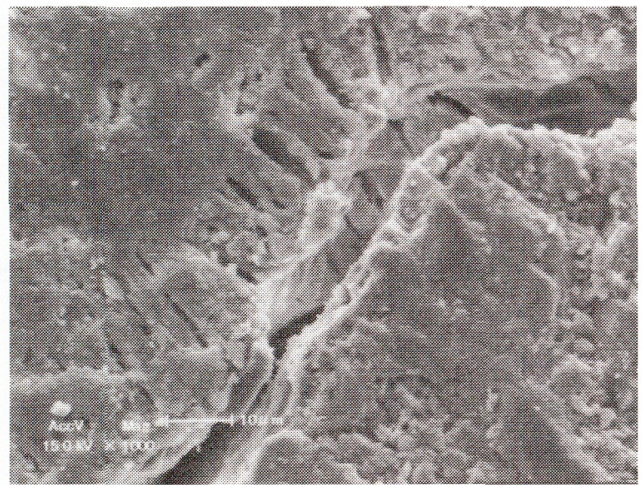

写真-5 石灰石骨材界面に生成したエトリンガイト

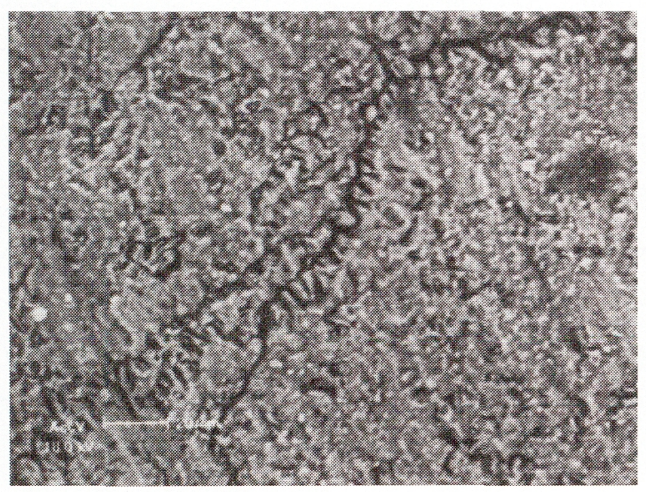

写真-6 マイクロクラック中のエトリンガイト

るため，各種分析および実験を行った。

\section{4. 澎張劣化の原因}

\section{1 エトリンガイトの生成箇所の特定}

異常膨張を生じたコンクリート二次製品中にエトリン ガイト，二水せっこうが生成していたことから，これら の生成箇所を特定する必要がある。そこで，本研究は X 線分析顕微鏡（XGT）によりコンクリート二次製品断 面の各種元素マッピングを行った。

写真-4（a）（c）は異常膨張を生じたコンクリート二 次製品の $\mathrm{Ca}, \mathrm{S}$ 元素マッピングを示している。

Caに着目すると，元素分布に偏りが無く，問題無い
むのと考えられる。Sに着目すると，異常嘭張を生じた コンクリート二次製品においては，S は石灰石骨材界面 付近に集積している状況が確認できる。Sの集積してい るレイヤーは約 $10 \mu \mathrm{m}$ 程度であり，その他の異常膨張 を生じたコンクリート二次製品においてもS の集積状 況が確認された。また，セメント硬化体中のマイクロク ラックに沿って Sの多い箇所屯確認できる。以上のこ とから，エトリンガイトおよび二水せっこうは石灰石骨 材界面抢よびマイクロクラック中に生成しているむの上 推察された。

さらに石灰石骨材界面をSEMにより観察した結果, 写真-5に示すように石灰石骨材界面に生成物が確認さ れた。SEM 付属の EDX によりこの生成物を分析した ところ，この生成物はエトリンガイトであると判断され た。さらに，湾曲 IPX 線回折装置により石灰石骨材界 面生成物の組成分析を行ったところ，エトリンガイトが 確認された。また，写真-6 に示すようにマイクロクラッ クに沿ってエトリンガイトが生成している状況屯確認さ れた。

\section{2 蒸気養生温度の測定}

異常膨張を生じたコンクリート二次製品はいずれも蒸 気養生を行っている。一般的な工場製品の蒸気養生はコ ンクリートにひび割れやはく離, 変形を生じさせないよ うに以下のように定めている9 。

1）型枠のまま蒸父養生室に入れ，養生室の温度を均 等に上げる。

2）練混ぜた後，2３時間以上経ってから蒸気養生 を行う。

3）温度の上昇速度は 1 時間につき 20 度以下とし, 最高温度は 65 度とする。

4）養生室の温度は徐々に下げ，外気の温度と大差が ないようになってから製品を取り出す。

そこで，本研究はあるコンクリート二次製品工場の蒸 気養生温度を定期的に測定した。図-3，図-4に膨張し たコンクリートを製造したコンクリート工場においてコ 


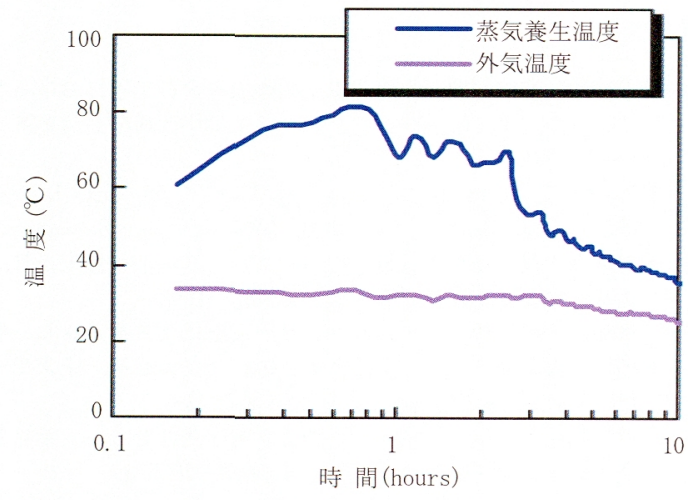

図-3 蒸気養生温度の一例

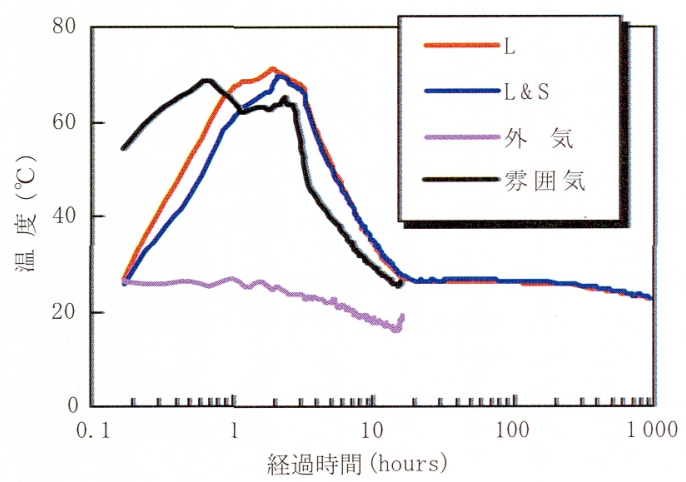

図-4 蒸気養生によるコンクリート中の温度変化

ンクリートの蒸気養生時に測定した霝囲気温度とコンク リート温度の一例を示す。

図-3を見ると，本研究で測定したコンクリート工場 の蒸気養生温度は蒸気養生開始後, 急激に温度が上昇し, 一般的な蒸気養生温度である $65^{\circ} \mathrm{C}$ をはかに超えた 82 ${ }^{\circ} \mathrm{C}$ 付近にまで到達していることが分かる。また，測定 結果はコンクリートの温度ではないことから，コンクリー トの温度はさらに上昇し，コンクリートに悪影響を及ぼ している屯のと考えられる。なお，コンクリートの前養 生時間については 40～60 分程度であり，蒸気養生時間 は約 3 時間であった。蒸気養生後は外気温度とほぼ同程 度となる 12〜15 時間後に脱型した。

図-4 は蒸気養生温度とともにコンクリート中におけ る温度の測定結果を示す。「L\&S」は実際に異常膨張を 生じたコンクリート二次製品と同じ配合であり，「L」 は示方配合の細骨材を全て石灰石で置換して製造したコ ンクリートを示している。コンクリート中の温度は，雺 囲気温度に伴い上昇し，最高温度は雲囲気温度の最高温 度よりも高くなっていることが分かる。本研究では，あ るひとつの工場における蒸気養生温度を测定しており, 測定ごとに丞気養生温度が異なっていた。ロットによっ ては $80^{\circ} \mathrm{C}$ を超えるような高温蒸気養生を受けたコンク リート二次製品が存在し，それらが実環境下において膨 張した可能性が考えられる。すなわち，コンクリート二 次製品の製造ロットによってはコンクリート温度が 90 ${ }^{\circ} \mathrm{C}$ 以上となり，初期に生成されるエトリンガイトを強 制的に分解した可能性があると考えられる。
以上のことは，コンクリート硬化時において過剩な蒸 気養生を行った際に初期水和の際に生成されるエトリン ガイトが分解され, 硬化後に再生成する DEF である可 能性があることを裹付けている。

また，銅スラグの混入による違いに着目すると，最高 温度はほとんど変わらないものの，銅スラグ無混入のコ ンクリートの昇温速度が早いことが確認される。この原 因としては未解明であるが，石灰石骨材がセメントの水 和反応を促進した可能性が考えられる。

\section{3 DEF を生じた主要因の推定}

以上のことから，異常膨張を生じたコンクリート二次 製品の特徵として石灰石骨材界面においてエトリンガイ トが生成されていたこと, 製造ロットによっては最高温 度 $80^{\circ} \mathrm{C}$ を超えるような過剩な蒸気養生を行っていた可 能性があること，の2 点が明らかになった。

一般的に, DEF は高温養生によって遅延型エトリン ガイトが生成され，膨張する現象である。エトリンガイ 卜の温度の安定限界は $\mathrm{pH}$ によっても異なるものの, 70〜 90 ${ }^{\circ} \mathrm{C}$ と考えられている ${ }^{10)}$ よって，コンクリート 二次製品の製造ロットによっては, コンクリート温度が $90^{\circ} \mathrm{C}$ 以上となり, 初期に生成されるエトリンガイトが 強制分解された可能性があると考えられる。

さらに，李ら ${ }^{11)}$ は $\mathrm{C}_{3} \mathrm{~A}-\mathrm{CaSO}_{4}{ }^{-} \mathrm{CaCO}_{3}$ 系の水和反応に おいて, DEF の可能性を示唆している。モノサルフェー トが $\mathrm{CaCO}_{3}$ と反応してモノカーボネートやヘミカーボ ネートを生成する際, 硫酸イオンを放出する。これによっ てモノサルフェートやゲル状水和物と硫酸イオンが反応 しエトリンガイトを再び生成するとしている。また， $\mathrm{DEF}$ を生じるための条件は石灰石微粉末や二水せっこ うの添加量によって変化するため, 限定的な領域におけ るもの上している。本研究が対象としたコンクリート二 次製品は石灰石骨材であるが，石灰石骨材界面のみにお いてエトリンガイトが生成されていたことを考慮すると, その可能性も否定できない。

よって, 本研究が対象としたコンクリート二次製品に おける遅延型エトリンガイト生成による膨張劣化は, 過 剩な蒸気養生と石灰石骨材の 2 点が主要な要因となった 可能性があると考えられる。

Collepardi ${ }^{12}$ は, DEF には3つの要素が必要不可欠で あるとしている。1つはエトリンガイトが局所的に生成 するためのマイクロクラックの存在であり，2つ目とし て硬化後に生じる硫酸塩の放出, 最後に水の存在である。 本研究が示したコンクリート二次製品はこれら 3 点を満 足しているもの上考えられ，DEF による劣化であるこ とを示唆している。

本研究が対象としたコンクリート二次製品は他のセメ ントよりも $\mathrm{C}_{3} \mathrm{~A}$, せっこうの多い白色ポルトランドセ メントと石灰石を用いたコンクリートを蒸気養生させた 場合に生じた劣化事例である。しかし，一般的なセメン 
トを用いた場合でもこのような劣化は今後発生する可能 性があると考えられ, DEF に関する研究の推進および 早期対応の検討が必要である。

\section{5. 結 論}

本稿はコンクリート二次製品の異常膨張現象について 紹介したものである。過剩な蒸気養生を行うことにより 初期の水和に影響を及ぼし，コンクリート硬化後におい てエトリンガイトを生成する Delayed Ettringite Formation（DEF）である可能性が高いこと，石灰石骨材 を使用することにより劣化の促進効果があった可能性が あること，の 2 点を示した。

謝 辞 本研究における各種分析は九州大学中央分析 センターの装置を利用した。また，石灰石および銅スラ グの反応性について, 九州大学大学院理学研究院島田允 堯名誉教授にご指導頂いた。ここに厚く御礼申し上げる。

\section{参 考 文 献}

1）土木学会：コンクリートの化学的侵食・溶脱に関する研究の現状,
コンクリート技術シリーズ 53,2003

2）松下博通・演田秀則・牧角龍憲：硫酸塩を含む土堹におけるコン クリートの劣化, 第 8 回コンクリート工学年次講演会論文集, pp. 225 228, 1986

3) Tang Mingshu et al. : Studies on Alkali-Carbonate Reaction, ACI Materials Journal, pp.26-29, 1994, January-February

4）土木学会：銅スラグ細骨材を用いたコンクリートの施工指針，コ ンクリートライブラリー 92, pp. 36〜42, 1998

5）鳥居和之・友竹博一：アルカリシリカ反応によるモルタルの膨張 挙動に及ぼすセメントと反応性骨材の組合せの影響, 土木学会論 文集, No. 739/V-60, pp. 251〜263，2003.8

6）二戸信和ほか：生コン供給を可能にする耐酸性セメント系材料の 開発，セメント・コンクリート，No.698, 2005.4

7) N.J. Crammond: The thaumasite form of sulfate at-tack in the UK, Cement and Concrete Composites, Vol.25, pp.809-818, 2003

8）羽原俊祐：硫酸塩膨張と DEF, セメント・コンクリート, No. 671, pp. 61 62, 2003

9）土木学会：コンクリート標準示方書 [施工編], pp. 252 253, 2002

10) H.F.W. Taylor, C. Famy, K.L. Scrivener : Delayed ettringite formation, Cement and Concrete Research, Vol.31, pp.683-693, 2001

11）李 琮撥ほか： $3 \mathrm{CaO} \cdot \mathrm{Al}_{2} \mathrm{O}_{3}-\mathrm{CaCO}_{3}$ 系および $3 \mathrm{CaO} \cdot \mathrm{Al}_{2} \mathrm{O}_{3}-\mathrm{CaSO}_{4}$ $\cdot 2 \mathrm{H}_{2} \mathrm{O}-\mathrm{CaCO}_{3}$ 系の水和反応, セメント・コンクリート, No. 627 , pp. $56 \sim 62,1999.5$

12) M. Collepardi : A state-of-the-art review on delayed ettringite attack on concrete, Cement\&Concrete Composites, Vol.25, pp. 401-407, 2003

\section{新玵紹介}

\section{社団法人＼cjkstart建設コンサルタンツ協会 『Consultant』編集部 編}

\section{土木遺産 \\ 世紀を越えて生きる㕡知の結晶 \\ ヨーロッパ編}

ダイヤモンド社 / B 5 判 $/ 197$ ページ / 2200 円十税

(2005. 6)

古来より, 物作りを通じて得た多くの経験は, 人伝てに次の 世代に受け継がれ，この伝承の過程で淘汰され，人々にとって 有益な匠の技として遺されてきた。

ここ数十年の多方面にわたる科学技術の発展は目覚しく，建 設技術において屯多くの新材料や新工構法の開発によって，建 設工事の大幅な効率化を実現し，多くの社会基盤施設の速やか な整備に貢献してきた。近年，「公共に有益な社会基盤施設を
厳選し，それらをいかに長期にわたって供用していくか」が強 く求められており, 社会の変化に適応した淘汰の時代になって いる。

本書は，ローマ時代の高速道路を皮切りに，ヨーロッパ各地 で, 紀元前から数百年前に造られた土木構造物について, 当時 の社会情勢や文化などの歴史的背景に触れながら，その時代の 先端材料と技術を駆使した建設工事とそれを末永く供用するた めの維持管理の工夫を興味深く解説している。

紙面を飾る絵葉書のような景観写真は，一見，観光名所や遺 跡めぐりのように錯覚するが，いずれも世紀を越えて，今でも 人々の生活を支え続けている現役の社会基盤施設であることに 驚かされる。これが本書のタイトルを遺跡でなく「土木遺産」 とする所以であるが, 長い年月の間, 公共に有益な遺産となり 得るには，建設に携わった造り手の情熱と耪智もさることなが ら，それを大切に守り続けようとする人々の強い信念があって， 漸く成し遂げられることが伺える。

専門家以外でも知的好奇心を十分に満足する内容でありなが ら，専門家にとっては，公共に有益な社会基盤施設のあるべき 姿とは何か，その本質を改めて教えてくれる一冊である。

（記：新藤 竹文） 